\title{
Under the Environment of Supply Chain Logistics Outsourcing Decision and Risk Research
}

\author{
Guo Xiwei \\ School of Economic and Management \\ Shenyang Aerospace University \\ Shenyang China
}

\author{
Wei Da \\ School of Economic and Management \\ Shenyang Aerospace University \\ Shenyang China
}

\begin{abstract}
With the integration of the global economy and the development of information technology, the cooperation between enterprises is increasingly strengthened. Transnational cooperation in the region and even the whole trend is increasingly obvious. In the fierce competition environment in order to gain competitive advantages, the enterprise will closely cooperate with upstream and downstream enterprises, implement supply chain management. With this adaptation, logistics outsourcing services have become critical factor in lower operating costs, enhancing core competitiveness as well as improving enterprise responsiveness. Logistics outsourcing bring economic befits to the enterprise. However, it also exits so many hidden risks that logistics outsourcing are often suspended or even ended in failure. Consequently, it is important to set risk awareness and introduce risk management in the logistics outsourcing. Aiming at the risks that may arise during the logistics outsourcing activities, this paper detailedly gives a comprehensive identification, analysis and evaluation of those risks by utilizing a systematic and scientific method, actively explores some effective preventive measures, and systematically establishes a set of risk management, which possesses crucial theoretical and practical significance.
\end{abstract}

Key words: Logistics outsourcing; Third Paryty Logistics; Outsourcing Decision; Logistics outsourcing Risk

\section{INTRODUCTION}

With economic globalization and the development of information technology, cooperation between enterprises is increasingly strengthened, and the upstream and and downstream enterprises among suppliers and distributors are in close cooperation on the implementation of supply chain management. In the supply chain environment, logistics outsourcing has become an important means for many companies to expand income, and it can also reduce the logistics cost of enterprises so that the enterprises can enjoy more professional third-party logistics services, as well as lower the capital investment of enterprises, to enable them to focus more on their core business. Although there are many benefits of logistics outsourcing, there are also a lot of risks, so logistics outsourcing decision making is particularly important. Therefore, it is extremely significant both in theory and in practice to actively explore effective measures to prevent risks, and establish a sound management system.

\section{THE RESEARCH STATUS AT HOME AND ABROAD}

\section{A. Foreign Research Overview}

Globally, especially in the developed countries such as Europe and America, logistics outsourcing has many years of development history. In the recent years, with the global expansion of world economy, the buyers and sellers of third-party logistics service have accumulated more experience in their respective fields. The third-party logistics industry is undergoing transformation, and logistics outsourcing is more vigorous and developing rapidly. International logistics outsourcing is showing marked features that the service provided by third-party logistics is more and more competitive in efficiency and cost, and the third-party logistics suppliers gradually transform from business cooperation to "strategic partnership" and "resource managers".

\section{B. Domestic research overview}

On the development of third-party logistics in China, most Chinese enterprises have their own transportation and warehousing departments or companies now, to pursue the policy of hold profit indoors by implementing selfsupporting logistics. There is great potential to be explored among the Chinese enterprises in utilizing the third-party logistics service so as to improve logistics management benefit.

At present, the theoretical research on logistics outsourcing made by scholars at home and abroad has been rather abundant and comprehensive, but research on logistics outsourcing risk has just started and is still in the exploratory stage. The research is still stuck in the qualitative analysis and description of the risks in terms of theories and experience, without systematic and quantitative research and analysis as well as actual operational research on risk prevention.

\section{II. RELEVANT THEORIES OF LOGISTICS OUTSOURCING IN SUPPLY CHAIN ENVIRONMENT}

Enterprise logistics outsourcing is one of the main ways of business outsourcing, logistics outsourcing plays an important role in enhancing the competitive edge of enterprises. Today when supply chain theory and practice are continuously deepening, the research on logistics 
outsourcing has to be carried out in the environment of supply chain management.

\section{A. The concept of logistics outsourcing}

Logistics outsourcing, also known as third-party logistics or business logistics, means that an enterprise entrusts the logistics activities originally done by the enterprise itself to a third-party logistics service enterprise by signing a contract with the latter. Besides, it is an operation and management mode by keeping close touch with the third party logistics activities enterprise through the information system, so as to achieve the management and control of the whole logistics process of its own.

Third-party logistics is a logistics form in which the third party professional enterprises relative to the first party consignors and the second party consignees undertake the logistics activities. Through cooperation with the first and second parties, the third party logistics enterprises provide their specialized logistics services. They neither have products nor participate in commodity trading, but contractually bound to provide serialized, personalized and informational logistics agency service for the customers based on alliance, including the design of logistics systems EDI capabilities, statement management, cargo transport, carrier selection, freight forwarders, customs agents, information management, warehousing, consultation, freight payment and negotiations and so on.

\section{B. The relationship between supply chain management and logistics, logistics outsourcing}

In supply chain management mode, enterprises put forward higher requirements on logistics operation and management. Outsourcing logistics operation is an inevitable development trend for the supply chain node enterprises. That the supply chain node enterprises outsource their own logistics to third parties is known as third-party logistics.

(1)Strategic relation. In terms of service content, when logistics is outsourced to third-party logistics, what the third party logistics provides for customers is not just oneoff transport or delivery service, but long-term integrated logistics services with a longterm contractual nature, the ultimate function of which is to ensure that the efficient operation of the logistics system of the service object and the continuous optimization of supply chain management.

(2) The parties undertaking logistics outsourcing ---third party logistics enterprises are both the strategic investors of the supply chain node enterprises and risk bearers. What the third-party logistics enterprises pursue is not short-term economic benefits, but to be precise, 3PL provides services to supply chain node enterprises as investors, which is its typical feature of becoming strategic ally.

(3) Interests integration is the profit base of logistics outsourcing. It can be said that the saving of inventory cost is the new value created by the logistics science, which is shared by third party logistics enterprises and supply chain node enterprises. This is the integration of interests, and the benefit sharing brought by the "win-win strategy" emphasized by the modern enterprise competition theory.

\section{The reasons for enterprises to adopt self-supporting logistics / outsourcing decision making}

Logistics outsourcing itself is not enterprises' strategic objectives, but is merely a way to achieve strategic objectives, so before making a decision, enterprises should be clear about which are their core competitiveness and the theoretical knowledge of transaction cost and agency, etc, to make better decisions.

\section{ANALYSIS OF DECISION MAKING OF ENTERPRISES IN LOGISTICS OUTSOURCING IN THE SUPPLY CHAIN ENVIRONMENT}

In this period when the logistics management and technology keep improving and the third-party logistics develops rapidly, there are both advantages and disadvantages for enterprises to adopt the self-supporting logistics or logistics outsourcing. Adopting logistics outsourcing can reduce cost and improve customer service level. Undoubtedly, an inevitable problem is the decision making in self-supporting logistics and logistics outsourcing. In this chapter, it will be discussed in detail what decision-making methods and principles the enterprises have to adopt in the decision making process of self-supporting and outsourcing logistics and what are the factors that influence their decision making.

\section{A. Principles to be followed in decision-making}

For enterprises, the implementation of logistics outsourcing decision is to select a decision from the logistics decision set to implement.

\section{1) Analysis of the strategic importance of systems}

When making outsourcing decisions, the enterprises must first consider the strategic importance of the logistics subsystem. It generally can be judged from the following aspects to determine whether the logistics subsystem is an enterprise's core competency:

(1)whether it has a great influence on the enterprise's business process;

(2) whether relatively advanced technology is needed;

(3) whether it can be imitated by other companies in the short term.

\section{2) Enterprise logistics capacity analysis}

Enterprise logistics capability mainly refers to whether a company has the facilities, tools, and funding to implement a logistics activity. If companies do not have the logistics capability, they can outsource logistics activities; if they have, they can consider self-supporting logistics.

3) Enterprise logistics cost analysis

For enterprises which have the logistics capability, it does not mean that they must adopt self-supporting logistics. They shall compare themselves with logistics outsourcing suppliers, to find whose cost is lower on the premise of achieving a certain level of customer service. Only when the cost of enterprises is lower can they get benefit by choosing self-supporting logistics, or they should implement logistics outsourcing.

\section{B. Method of decision making}

In fact, self-supporting/outsourcing decision making is the starting point for logistics outsourcing. As for outsourcing decision making, the major decision-making methods are Ballow's decision making method and the 
decision making method of dividing logistics according to functions and then analyzing the capability and selfsupporting/cost and so on. Next, the methods used in decision making will be introduced briefly.

\section{1) Ballow's decision making method}

Ballow has presented the two-dimensional decision making criteria and argued that the use of self-supporting logistics or logistics outsourcing depends on the balance of the following two factors: how important logistics is to the success of an enterprise and the enterprise's ability to manage logistics. As shown in Figure 3.1, the position of the an enterprise decides the strategy it will pursue.

The importance of logistics for enterprises

Search for strong partner

Self-supporting logistics

Outsourcing

Become the core of cooperation system

Enterprises' ability to operate logistics

Figure 4.1 Logistics outsourcing decision making diagram developed by Ballow

On one hand, if logistics is not an enterprise's core strategy and the enterprise is not competent in logistics management, the logistics business outsourced to logistics service suppliers can help reduce costs and improve customer service quality.

If logistics is the core of an enterprise's business strategy but the enterprise is not competent in logistics management at the moment, it will bring benefit to the enterprise to find logistics partners. The advanced logistics facilities of good partners can provide service management at a level that the self-supporting logistics of the enterprise can not achieve.

2) The decision making method on overall consideration of logistics capability and cost

The process of the decision making method of dividing logistics according to functions and then analyzing the capability and cost is shown in Figure 4.2:

Establish enterprise process chart, logistics is core business, No, nonstrategic system

Classify the logistics operations according to functions, Yes, Classify the logistics operations according to functions

Strategic position: keep leading position, Yes, whether strategically significant, logistics operation ability, No

No, Yes

No, logistics operation, whether cost is competitive, No

Yes, Yes

No, cost competition

Self-supporting

Third party

Figure4.2 Decision making flowchart

This method argues that when making decisions to outsource logistics, the enterprises shall first consider the importance of logistics to enterprise strategy.

\section{THE RISKS IN LOGISTICS OUTSOURCING IN THE SUPPLY CHAIN ENVIRONMENT AND PREVENTION}

Now, the environment for enterprises to develop is undergoing drastic changes. Accordingly, logistics outsourcing has become the key for enterprises to reduce operating costs, enhance their core competitiveness and improve reaction speed. While bringing benefit to enterprises, the logistics outsourcing also involves many hidden risks, which can cause various problems in logistics outsourcing, suspension and even failure of logistics outsourcing activities.

\section{A. Analysis of the risks of logistics outsourcing}

In the outsourcing process, usually enterprises and TPL will achieve coordination by way of signing contracts, but due to information asymmetry, cultural differences between the collaborative enterprises, various risks turn up continuously. In order to avoid risks, companies must first understand what the risks are. In the process of logistics outsourcing, there are mainly the following risks.

1) Management Risk

Logistics outsourcing risk management is the management risk in cooperation caused by the different management modes of enterprises and their logistics suppliers in cooperation.

\section{a) Risk in Enterprise Management}

The logistics managers of enterprises should know how to manage the logistics outsourcing and how to maintain business partnership between enterprises and logistics suppliers. If TPL suppliers change the mode of providing logistics services, enterprises must adapt as quickly as possible, and if the logistics suppliers implement personnel adjustment, they should also adapt to the environmental changes brought about by the other parties' personnel adjustment as soon as possible.

b) Lose control of logistics suppliers

In the process of cooperation between enterprises and logistics suppliers, enterprises may gradually take a disadvantage position and may eventually lose control of logistics operations. Enterprises should weigh their decisions on relying on a logistics supplier for a long term or relying on several logistic suppliers.

\section{2) Information risk}

In the course of logistics outsourcing cooperation, the obstacle in communication, information feedback lag and information distortion between enterprises and logistics suppliers add to the information asymmetry of logistics outsourcing cooperation. If the collaborative enterprises do not want to share information, it will result in obstacles in the communication in the whole logistics outsourcing cooperation and the information leakage and risk formed accordingly in the process of information sharing.

\section{3) Financial risk}

Another risk of logistics outsourcing is the financial risk within enterprises. In the early stages of logistics outsourcing, the logistics cost of enterprises is difficult to calculate clearly, and after the operation of logistics outsourcing is finished, it will be found that the operation cost is seriously overspent, so the enterprises can not achieve the desired effect.

\section{4) Market risk}

The so-called market risk is the investment losses due to the fluctuations of fund net value or price along with the fluctuations in market price of the investment objectives. There are fluctuations in price in the logistics market. After outsourcing logistics, the enterprises' logistics innovation ability will decrease, which will result in market risk. 


\section{B. Prevention measures for logistics outsourcing risks}

With the promotion of logistics outsourcing practices, companies should not only consider the advantages of logistics outsourcing on making the selection but also pay attention to its potential risks, to decide to outsource logistics by taking a systemic and longterm viewpoint and take some measures to prevent the potential risks.

\section{1) Identify the core competitiveness of enterprises}

Outsourcing itself is not a business development strategy of enterprises, but is just a way of achieving the enterprise strategy, so enterprises should determine whether there are competent and selectable logistics suppliers in the industry, or the implementation of logistics outsourcing will not be successful and will even lead to a series of problems. Therefore, it seems rather important for enterprises to make an in-depth analysis of their internal logistics situation and discuss whether the logistics is their core competency.

\section{2) Selection of outsourcing partners}

An important question in logistics outsourcing decision making is who the enterprises shall outsource their logistics to, that is, the selection of outsourcing partners. First, it is needed to investigate, analyze and evaluate the potential external logistics suppliers, to investigate those logistics suppliers' management situation, strategic direction, IT support capabilities, their plasticity and compatibility and industry operating experience and so on, to evaluate their cost situation in working on logistics activities, long-term development ability and credibility and so on. In particular, enterprises must make analysis and weigh seriously the commitment and pricing of the logistics suppliers

\section{3) Control of logistics outsourcing activities}

The monitor and control of outsourcing activities ensures the smooth implementation of outsourcing. Even though enterprises have signed contract with third party logistics suppliers, they shall also monitor the performance of third-party logistics suppliers, and provide them with the necessary business information. The enterprises and third-party logistics suppliers shall pay attention to communicating with each other, jointly developing operating guidelines. To establish control mechanisms for logistics outsourcing, enterprises should regularly check the performance of the outsourcing partners and develop standards for the evaluation of their performance.

4) Consolidate partnership following the "win-win" principle

The logistics suppliers' service competence for enterprises and enterprises' customers depends on the enterprises' own working performance. Outsourcing means the interests of both sides are tied together and not separated. Good partnership will benefit both parties, and the poor performance of either party will make both parties suffer losses. When selecting logistics suppliers, the enterprises shall change the existing views to only focus on improving the core competitiveness of enterprises but neglect the interests of logistics suppliers. Enterprises should treat logistics outsourcing with a far-reaching strategic idea, not only to maximize their own interests through logistics outsourcing, but also promote the continuous and steady development of logistics suppliers, so as to achieve a win-win situation. Therefore, the key factor for building good outsourcing cooperation relationship is that the supplying and demanding parties trust and keep loyalty to each other and fulfill their commitment.

\section{CONCLUSION}

This paper focuses on logistics outsourcing, to investigate the status of development of logistics outsourcing decision making and risks in the supply chain environment in China and analyze the relevant problems. Besides, it is explored actively how to effectively prevent the risks and establish a set of complete management system, to better improve the core competitive advantage of enterprises. It is of great significance in theory and practice.

The development prospect of logistics outsourcing is undoubtedly very optimistic. Although the third-party logistics market is not very mature, under the demonstration and competitive pressure of multinational companies, as the enterprises in China get a deep understanding, the third-party logistics is bound to attract attention by its professional level and high quality service and logistics outsourcing will get further development.

\section{REFERENCES}

[1] Xu Guobing. Enterprise logistics outsourcing risk alarming system based on case reasoning. Logistics Technology, 200726 (9): 22-24

[2] Yang Danhui, Jia Wei. Research on enterprise outsourcing decision making model. Journal of Capital University of Economics and Business. 2007. (3): 29-33.

[3] Yang Da. Research on enterprise logistics outsourcing decision making based on core competence. Railway Transport and Economy 2008. (11): 67-68

[4] Tu Xianhao, Logistics outsourcing risk assessment based on risk matrix. Logistics Technology, 2006, (5)

[5] Zhu Huamin. Logistics Outsourcing Decision Analysis. Domestic Storage and Transportation, 2006, (5)

[6] Liu Lianhui, Wang Jianqiang. Enterprise Logistics Outsourcing Risk Analysis and Prevention. Journal of Hunan Institute of Engineering, 2005, 15 (4)

[7] Ma Shihua, Lin Yong, Chen Zhixiang. Supply Chain Management. Beijing: Mechanical Industry Press, 2003.

[8] Dwayne Whitten, Robin L. Wakefield. Measuring switching costs in IT outsourcing services. Journal of Strategic Information Systems.. 2006 (15): 219-248. 